\title{
A Titus Phase Midden Mound at the Earl Jones Farm (41WD3) in the Lake Fork Creek Basin, Wood County, Texas
}

Timothy K. Perttula

Heritage Research Center, Stephen F. Austin State University

Follow this and additional works at: https://scholarworks.sfasu.edu/ita

Part of the American Material Culture Commons, Archaeological Anthropology Commons, Environmental Studies Commons, Other American Studies Commons, Other Arts and Humanities Commons, Other History of Art, Architecture, and Archaeology Commons, and the United States History Commons

Tell us how this article helped you.

This Article is brought to you for free and open access by the Center for Regional Heritage Research at SFA ScholarWorks. It has been accepted for inclusion in Index of Texas Archaeology: Open Access Gray Literature from the Lone Star State by an authorized editor of SFA ScholarWorks. For more information, please contact cdsscholarworks@sfasu.edu. 


\section{A Titus Phase Midden Mound at the Earl Jones Farm (41WD3) in the Lake Fork Creek Basin, Wood County, Texas}

\section{Creative Commons License}

\section{(c) (1) \&}

This work is licensed under a Creative Commons Attribution-NonCommercial 4.0 International License 


\title{
A Titus Phase Midden Mound at the Earl Jones Farm (41WD3) in the Lake Fork Creek Basin, Wood County, Texas
}

\author{
Timothy K. Perttula
}

\section{INTRODUCTION}

The Earl Jones Farm site is one of a number of Late Caddo period, Titus phase (ca. A.D 1430-1680), sites along tributaries of Lake Fork Creek in the upper Sabine River basin in East Texas (Figure 1), nor far from Quitman, the county seat for Wood County. This includes sites such as J. H. Reese (41WD2), L. L. Winterbauer (41WD6), 41WD19, 41WD44, Pine Tree (41WD51), Burks (41WD52), and Steck (41WD529) with habitation features, midden deposits, and family cemeteries (Perttula et al. 1993:Figure 4; Perttula 2005; Perttula and Skiles 2014a, 2014b).

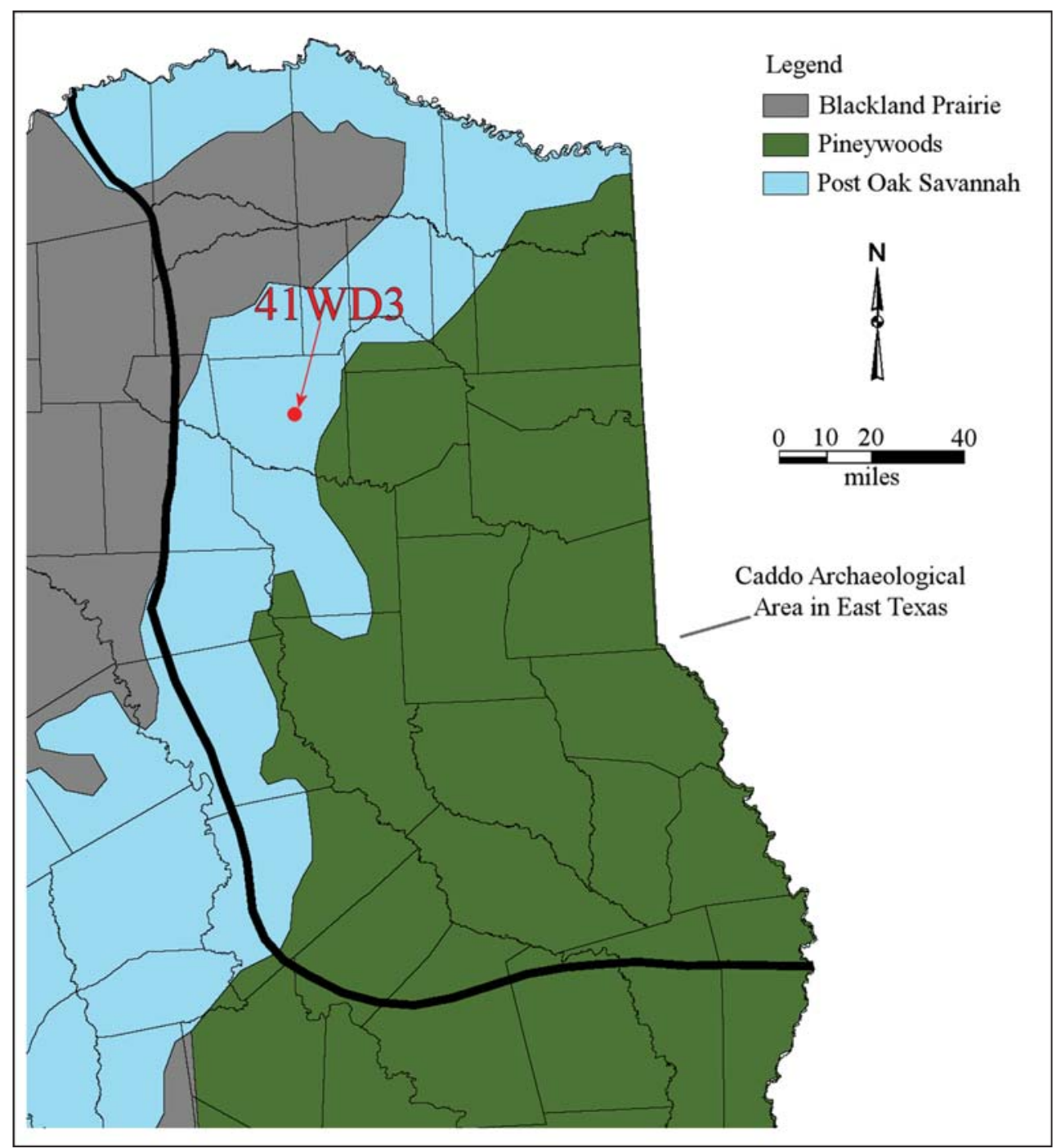

Figure 1. The location of the Earl Jones Farm site in the Post Oak Savannah of East Texas. 


\section{SITE SETTING AND PAST ARCHEOLOGICAL INVESTIGATIONS}

The Earl Jones Farm site was located and investigated by Wilson and Jackson (1930; see also Reese 1931) in August 1930. The work was done by digging trenches across the mound as "per suggestions of J. E. Pearce" (Wilson and Jackson 1930). It is a midden mound in the uplands on the east side of Muddy Creek, a southern- and westward-flowing tributary to Dry Creek in the Lake Fork Creek basin (Figure 2a); Little Dry Creek is well to the south of the site, and flows west into the Dry Creek basin.
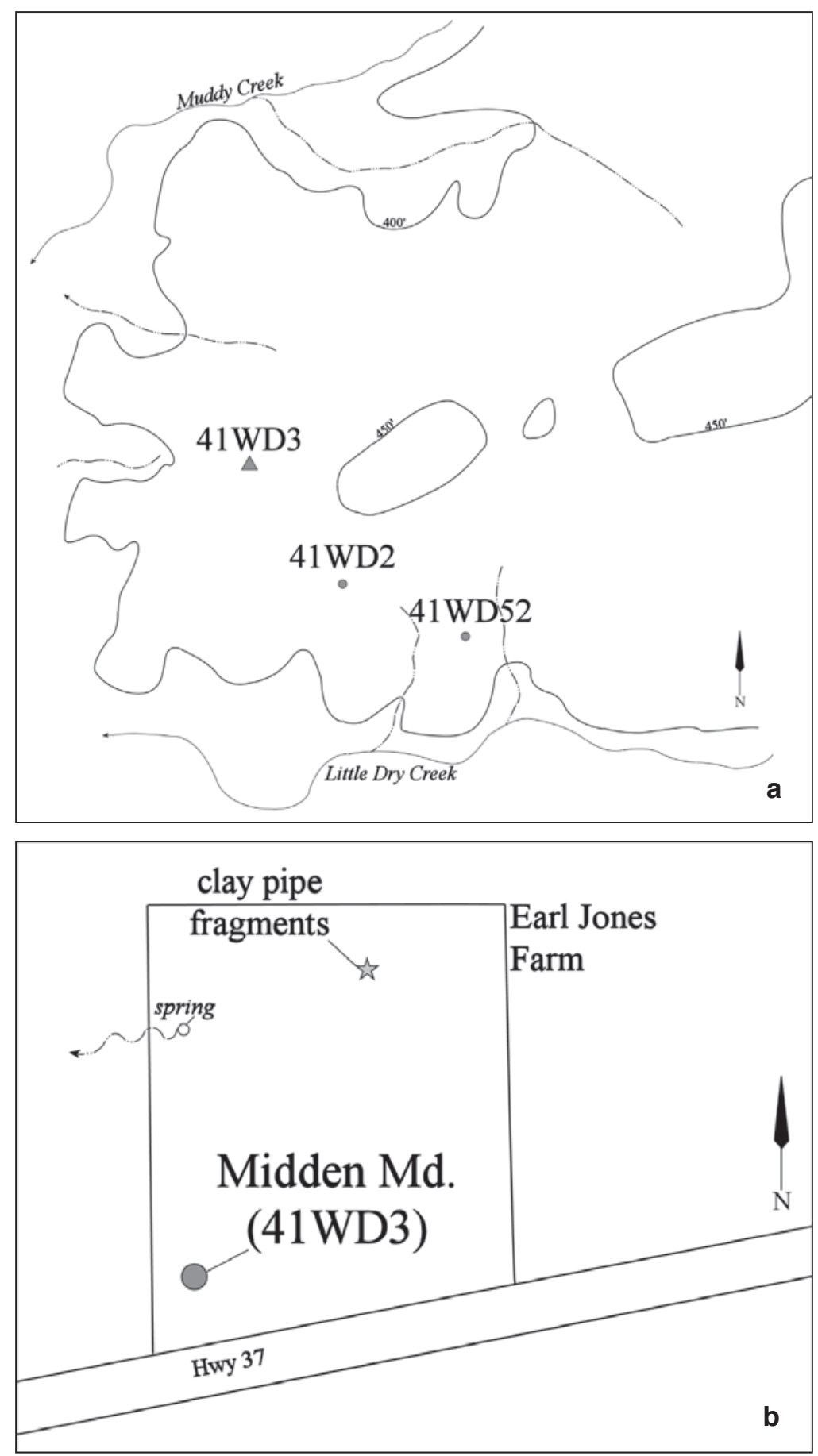

Figure 2. The setting of the Earl Jones Farm site: a, in the Muddy Creek valley; b, on the Earl Jones Farm (after Reese 1931:4). 
The site was on farm land owned by Earl Jones (Figure 2b). A small spring-fed tributary to Muddy Creek lay not far to the north of the site, and the J. H. Reese cemetery was about $180 \mathrm{~m}$ to the southeast. Ceramic pipe fragments reported by M. M. Reese (1931) to the northeast of the midden mound may mark the location of another ancestral Caddo site, or it may be part of the Earl Jones Farm Caddo settlement.

The midden mound was estimated to be ca. $9.2 \mathrm{~m}$ in diameter by Wilson and Jackson (1930) and ca. $0.6 \mathrm{~m}$ in height. As a concentrated trash deposit, it contained many ceramic sherds, animal bones, mussel shells, ashes, and charcoal, with most of these remains coming from ca. $15-30 \mathrm{~cm}$ bs; a portion of a dog skull-probably the remnants of a dog burial-was found on the southern side of the mound during the excavations. It is likely that there are or were preserved structural features and other evidence of permanent habitation by Caddo peoples around the midden mound, but Wilson and Jackson (1930) did not look for them during their investigations.

\section{ARTIFACT ASSEMBLAGE}

The Texas Archeological Research Laboratory, The University of Texas at Austin (TARL) artifact assemblage recovered from the excavations in the midden mound at the Earl Jones Farm site includes ceramic sherds $(n=437)$, one ceramic pipe, one clay plug/labret, six clay coils, two bone ornaments, and animal bones $(n=107)$. The latter included canid, deer, turtle, and one possible bison toe bone (1986 TARL inventory sheets).

\section{Ceramic Sherds}

The assemblage of ceramic sherds includes 266 plain rim $(n=3)$, body $(n=254)$, and base $(n=9)$ sherds and 171 decorated sherds from both utility ware and fine ware vessels. The sherds are from vessels tempered almost exclusively with grog or crushed sherds: only 0.6 percent of the decorated sherds are from a vessel tempered with burned bone.

The decorated sherds include 110 from utility ware vessels (64 percent of the decorated sherd assemblage), primarily if not exclusively from jars with wet paste decorative elements, and 61 sherds (36 percent of the decorated sherd assemblage) from fine ware bottles and carinated bowls (Table 1). Fine ware vessels have engraved decorative elements as well as a red slip on either one or both vessel surfaces. More than 61 percent of the rims from decorated vessels are from fine ware vessels.

Table 1. Decorated sherds from the Earl Jones Farm site.

\begin{tabular}{lccr}
\hline Decorative Method & Rim & Body & N \\
\hline Utility Ware & & & 20 \\
Appliqued & - & 20 & 36 \\
Brushed & - & 36 & 7 \\
Brushed-Appliqued & - & 7 & 15 \\
Brushed-Incised & - & 3 & 6 \\
Incised & 3 & 18 & 20 \\
Neck Banded & 2 & 3 & 5 \\
Punctated, fingernail & 2 & 1 & 1 \\
Punctated, tool & - & 103 & 110
\end{tabular}


Table 1. Decorated sherds from the Earl Jones Farm site, cont.

\begin{tabular}{lcrr}
\hline Decorative Method & Rim & Body & N \\
\hline Fine Ware & & & \\
Engraved & 11 & 38 & 49 \\
Engraved-red-slipped & - & 9 & 3 \\
Red-slipped $\quad$ Subtotal & - & 50 & 9 \\
$\quad$ Totals & 11 & 152 & 171 \\
\hline
\end{tabular}

The utility ware sherds are primarily from vessels with brushed, neck banded, appliqued, and brushedincised decorative methods (Table 2; see also Table 1). The brushed and brushed-incised sherds may be from the body of Bullard Brushed jars (Suhm and Jelks 1962:Plate 11), and the brushed-appliqued body sherds (Figure 3e) may be an unrecognized variety of the type or a variety of McKinney Plain (Suhm and Jelks 1962:97). On these sherds, the brushing on the vessel body is divided by sets (probably four around the body) of broad vertical appliqued ridges.

Table 2. Decorative elements on sherds from utility ware vessels.

$\begin{array}{llll}\text { Decorative element } & \text { Rim } & \text { Body }\end{array}$

\section{Appliqued}

closely-spaced parallel ridges

diagonal opposed ridges

horizontal and vertical ridges

straight ridge

Rim Body

$\mathrm{N}$

\section{Brushed}

parallel brushed

$-\quad 35$

35

vertical-diagonal brushed

$-\quad 1$

\section{Brushed-Appliqued}

parallel brushed-straight appliqued ridge

\section{Brushed-Incised}

parallel brushed-incised

$\begin{array}{ll}- & 14\end{array}$

14

parallel brushed zone and parallel lines

$-$

Incised

cross-hatched lines

hatched zone and concentric circles

parallel lines

\section{Neck Banded}

horizontal neck bands 
Table 2. Decorative elements on sherds from utility ware vessels, cont.

\begin{tabular}{lccc}
\hline Decorative element & Rim & Body & N \\
\hline $\begin{array}{l}\text { Punctated } \\
\text { fingernail punctated rows } \\
\text { tool punctated rows }\end{array}$ & 2 & 3 & 5 \\
\hline Totals & - & 1 & 1 \\
\hline
\end{tabular}

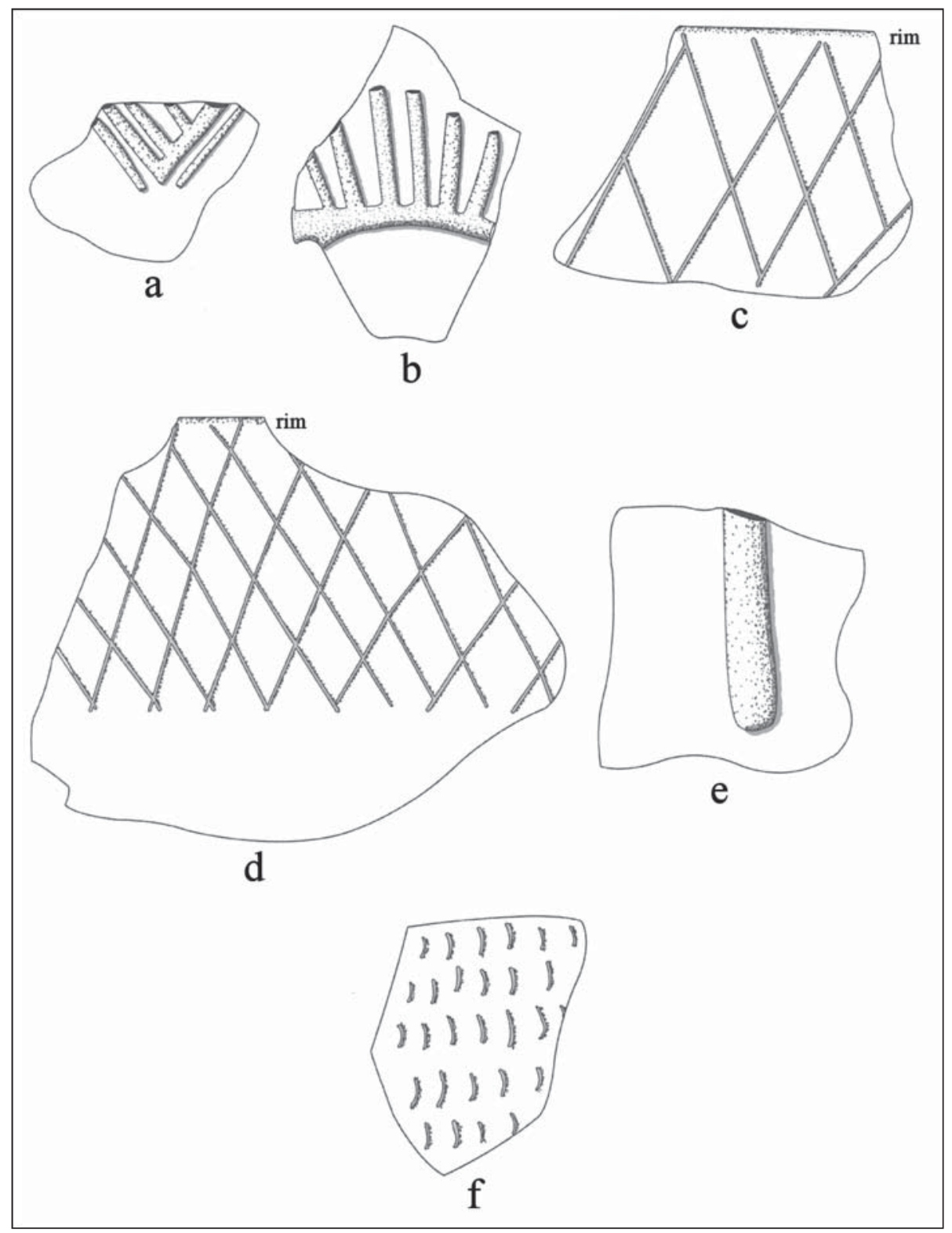

Figure 3. Decorative elements on utility ware sherds from the Earl Jones Farm site: a-b, Harleton Appliqued body sherds; c-d, cross-hatched incised rim sherds; e, appliqued body sherd; f, fingernail punctated rim sherd. 
Two of the appliqued body sherds are from Harleton Appliqued vessels (see Figure 3a-b). These have diagonal opposed and horizontal-vertical appliqued ridges. Another body sherd has closely-spaced parallel appliqued ridges, and the remainder of the appliqued body sherds (with a single straight ridge, likely oriented vertically on the vessel body) are probably from McKinney Plain jars (see Suhm and Jelks 1962:Plate 49a-b, f, h-i). All of the neck banded rim and body sherds are from La Rue Neck Banded vessels (Suhm and Jelks 1962:93 and Plate 47). The high frequency of neck banded sherds in the utility wares (18.2 percent) is comparable to other Titus phase ceramic assemblages in the Dry Creek and Little Dry Creek localities (Perttula et al. 1993:165).

Five of the incised rim and body sherds are from Maydelle Incised jars: these sherds have either parallel incised lines or cross-hatched incised lines (see Figure 3c-d). The sherds with punctated decorative elements comprise 5.5 percent of the utility wares (see Table 2). They have rows of either fingernail (see Figure 3f) or tool punctations on the rim and/or the vessel body.

About 15 percent of the fine ware sherds are decorated only with a red slip, including one sherd from a bottle (Table 3). Other Late Caddo period sites where red-slipped sherds are common in assemblages include Titus phase sites in the Big Cypress and upper Sabine River basins and 41HP175 in the upper Sulphur River basin (see Perttula 2015:Table 1).

Table 3. Decorative elements on sherds from fine ware vessels.

\begin{tabular}{|c|c|c|c|}
\hline Decorative element & Rim & Body & $\mathrm{N}$ \\
\hline \multicolumn{4}{|l|}{ Engraved } \\
\hline bracket element (el.) & - & 1 & 1 \\
\hline \multicolumn{3}{|l|}{ line } & 6 \\
\hline circle with excised pendant triangles & - & 2 & 2 \\
\hline \multicolumn{3}{|l|}{ and cross-hatched zone } & 1 \\
\hline cross-hatched zones and straight line & - & 5 & 5 \\
\hline curvilinear lines & - & 5 & 5 \\
\hline hatched zones and hatched triangle el. & - & $1^{*}$ & 1 \\
\hline horizontal lines & 1 & 2 & 3 \\
\hline horizontal-diagonal lines & 3 & 1 & 4 \\
\hline parallel lines & - & $6^{* *}$ & 6 \\
\hline parallel lines and hatched zone & - & 1 & 1 \\
\hline Ripley Engraved & 6 & - & 6 \\
\hline slanted scroll & 1 & 2 & 3 \\
\hline straight line & - & 8 & 8 \\
\hline \multicolumn{4}{|l|}{ Slipped } \\
\hline int./ext. red-slipped & - & 6 & 6 \\
\hline int. red-slipped & - & 2 & 2 \\
\hline ext. red-slipped & - & $1 * * *$ & 1 \\
\hline Totals & 11 & 50 & 61 \\
\hline
\end{tabular}


The remainder of the sherds from fine ware vessels at the Earl Jones Farm site have engraved decorative elements (see Table 3). Most of the decorative elements are from several varieties of Ripley Engraved carinated bowls (Figures 4b-g and 5b-e) and there is also at least one possible Wilder Engraved bottle sherd (Figure 5a). Other engraved sherds have cross-hatched zones and hatched triangles (Figure 4a), hatched zones, horizontal and diagonal engraved lines, and slanting scroll lines (see Table 3).

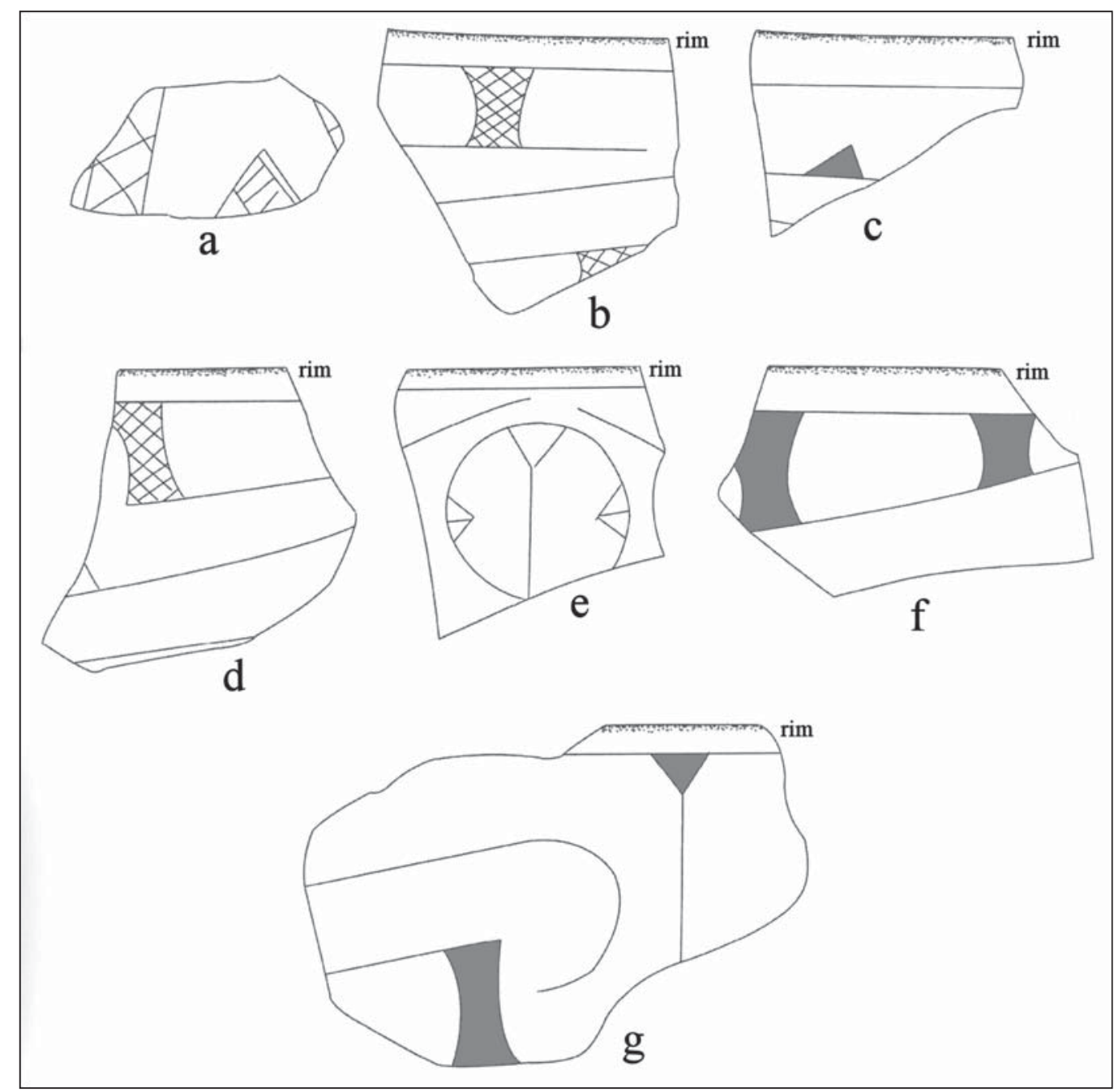

Figure 4. Decorative elements on fine ware sherds from the Earl Jones Farm site: a, engraved and red-slipped body sherd; b-g, rim sherds from Ripley Engraved carinated bowls.

Identified varieties of Ripley Engraved in the Earl Jones Farm ceramic assemblage include var. Galt (central circle element) (see Figures $4 \mathrm{e}$ and $5 \mathrm{~b}$ ) and var. Pilgrims (interlocking horizontal scroll) (see Figure $4 \mathrm{~g}$ ). Other rim sherds have slanted scrolls and either cross-hatched or excised upper and lower bracket elements, and these are probably from either var. Galt or var. Carpenter carinated bowls (see Figures 4b, d, f and 5e). The absence of the pendant triangle motif (Ripley Engraved, var. McKinney), as well as fine ware types such as Keno Trailed or Taylor Engraved, suggests that the Titus phase occupation at the Earl Jones Farm site likely pre-dates ca. A.D. 1550. 


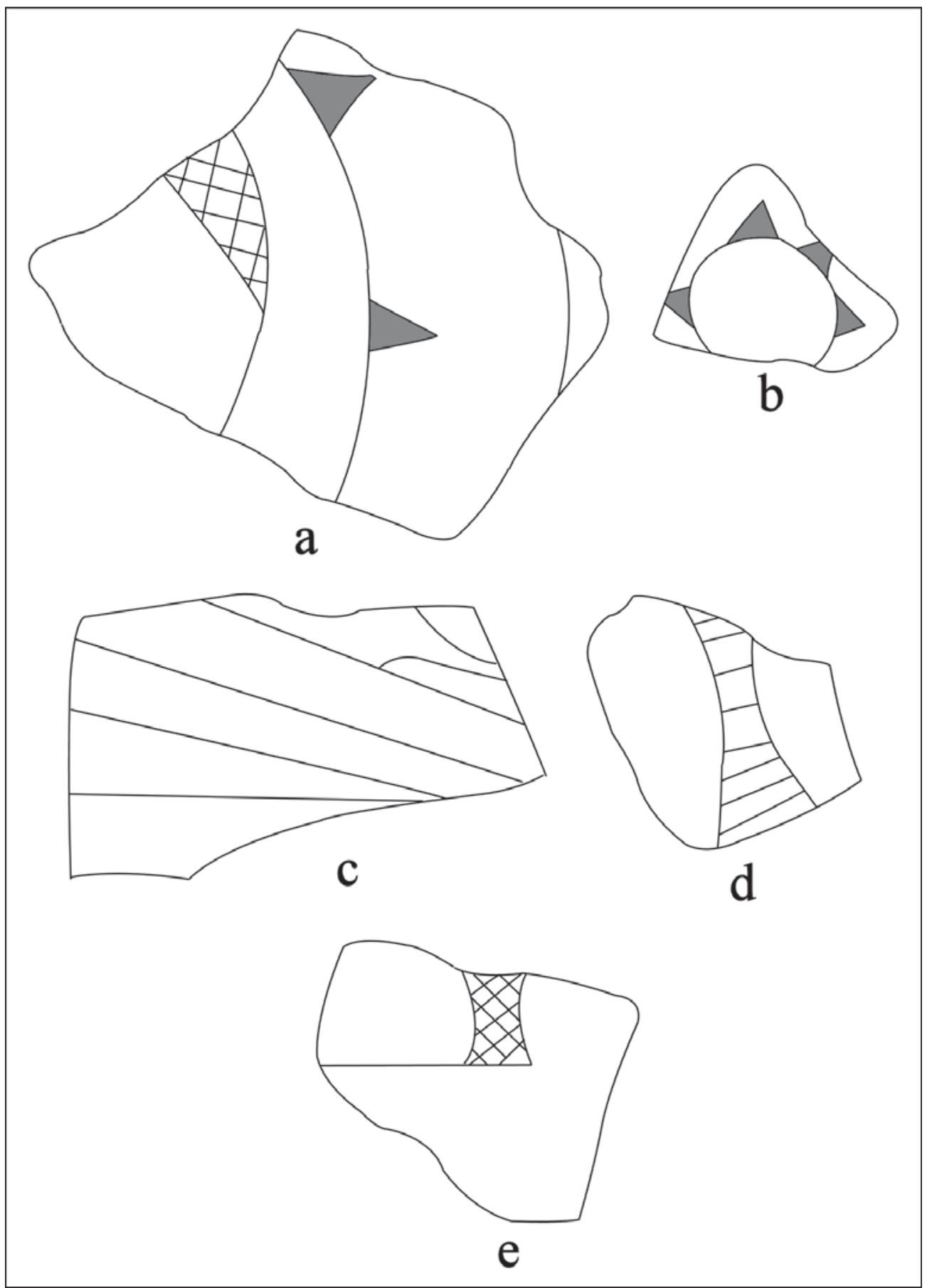

Figure 5. Decorative elements on fine ware body sherds from the Earl Jones Farm site: a, possible Wilder Engraved bottle sherd; b-e, Ripley Engraved body sherds.

\section{Ceramic Pipe}

A plain short-stemmed and short-bowled elbow pipe was found on the surface of the midden mound (Figure 6a). Jackson (1933:71 and Plate 16) has reported on similar plain and decorated elbow pipes in the Quitman area from Late Caddo period Titus phase occupations. 


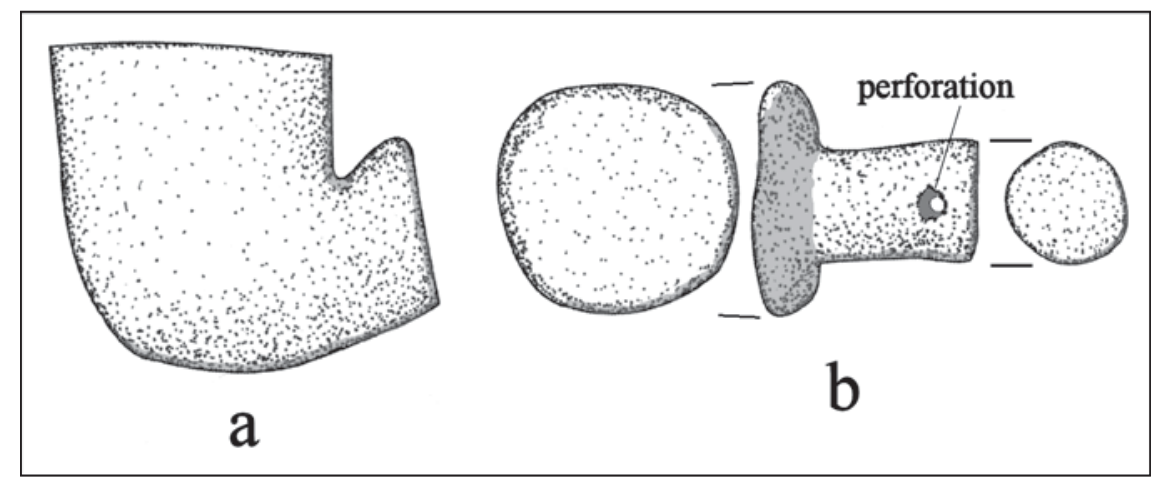

Figure 6. Other ceramic artifacts from the Earl Jones Farm site: a, elbow pipe; b, clay labret.

The pipe is tempered with grog and smoothed on its exterior surface. The pipe is $41.5 \mathrm{~mm}$ in height and $39.0 \mathrm{~mm}$ in width, with a $22.0 \mathrm{~mm}$ diameter at the stem. The short bowl has a $33.0 \mathrm{~mm}$ diameter, and the walls of the bowl are $6.2 \mathrm{~mm}$ thick.

\section{Other Ceramic Artifacts}

A clay plug or labret was found in the northern part of the midden mound excavations (see Figure 6b). The clay plug or labret is flat at either end, with 14.5 and $26.0 \mathrm{~mm}$ diameter ends. It is $23.0 \mathrm{~mm}$ in length and $15.2 \mathrm{~mm}$ in width. There is a $2.5 \mathrm{~mm}$ perforation near the smaller flat end, so this clay plug or labret would have been suspended by attachment through the perforation.

There are also six elongated clay coil lumps in the assemblage; they were recovered from $0-25 \mathrm{~cm}$ bs in the midden excavations. These clay coil lumps range from $28-82 \mathrm{~mm}$ in length and $21-34 \mathrm{~mm}$ in width.

\section{Bone Artifacts}

There are two polished bone ornaments in the midden collection; both are made from bird bones and were found on the midden surface. The first is a $83 \times 5.6 \mathrm{~mm}$ polished bone tube (Figure 7a), while the second is a polished bone bead that is $40.0 \mathrm{~mm}$ in length and $10.3 \mathrm{~mm}$ in diameter (Figure $7 \mathrm{~b}$ ).

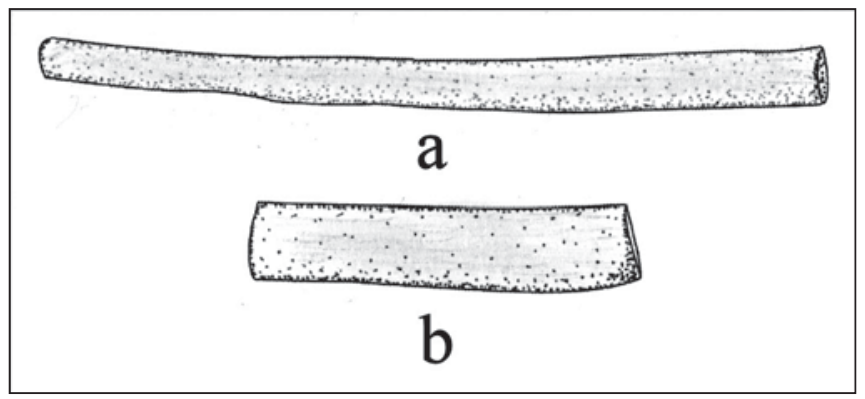

Figure 7. Bone ornaments from the Earl Jones Farm site. 


\section{SUMMARY AND CONCLUSIONS}

The Earl Jones Farm site is a Late Caddo period Titus phase (ca. A.D. 1430-1680) habitation site along a tributary stream in the Lake Fork Creek basin of the East Texas Post Oak Savannah. Titus phase habitation sites with midden mounds and family cemeteries are quite abundant in this part of the Lake Fork Creek basin as well as in adjoining drainages not far to the west (Bruseth and Perttula 1981; Perttula et al. 1993), suggesting a sizeable population of ancestral Caddo farming groups lived in this part of East Texas.

A. M. Wilson and A. T. Jackson investigated the midden mound at the Earl Jones Farm site in 1930. Other than a portion of a canid (dog) burial, the midden mound contained concentrations of ceramic sherds, animal bones, charcoal, and ashes in $0.6 \mathrm{~m}$ thick deposits, but no other features. The artifact assemblage recovered from the excavations in the midden mound at the Earl Jones Farm site includes ceramic sherds $(n=437)$, one ceramic elbow pipe, one clay plug/labret, six clay coils, two bone ornaments, and animal bones $(n=107)$ from canid, deer, turtle, and one possible bison toe bone. The ceramic sherds are from grog-tempered plain ware, utility ware, and fine ware, including sherds from Bullard Brushed, Harleton Appliqued, La Rue Neck Banded, McKinney Plain, and Maydelle Incised utility ware jars, as well as Ripley Engraved and Wilder Engraved fine ware carinated bowls and red-slipped carinated bowls and bottles.

\section{ACKNOWLEDGMENTS}

Lance Trask prepared the figures in this article. As always, Jonathan Jarvis facilitated access to the archival records and collections from the Earl Jones Farm site at the Texas Archeological Research Laboratory, The University of Texas at Austin.

\section{REFERENCES CITED}

Bruseth, J. E. and T. K. Perttula

1981 Prehistoric Settlement Patterns at Lake Fork Reservoir. Texas Antiquities Permit Series, Report No. 2. Texas Antiquities Committee and Southern Methodist University, Austin and Dallas.

Jackson, A. T.

1933 Some Pipes of East Texas. Bulletin of the Texas Archeological and Paleontological Society 5:69-86.

Perttula, T. K.

2005 The M. W. Burks Site (41WD52), A Late Caddo Hamlet in Wood County, Texas. Journal of Northeast Texas Archaeology 23:1-27.

2015 East Texas Caddo Ceramic Sherd Database. Journal of Northeast Texas Archaeology 51, in press.

Perttula, T. K. and B. D. Skiles

2014a The Steck Site (41WD529), a Titus Phase Settlement in the Lake Fork Creek Drainage Basin, Wood County, Texas. Journal of Northeast Texas Archaeology 48:1-8.

2014b Documentation of Late Caddo Period Ceramic Vessels from Sites in the Lake Fork Creek Basin in Wood County, Texas. Journal of Northeast Texas Archaeology 48:59-81.

Perttula, T. K., B. D. Skiles, and B. C. Yates

1993 The Goldsmith Site (41WD208): Investigations of the Titus Phase in the Upper Sabine River Basin, Northeast Texas. Bulletin of the Texas Archeological Society 61:139-191.

Reese, M. M.

1931 Report on Miscellaneous Sites in Wood County, Texas. MS on file, Texas Archeological Research Laboratory, The University of Texas at Austin. 
Suhm, D. A. and E. B. Jelks (editors)

1962 Handbook of Texas Archeology: Type Descriptions. Special Publication No. 1, Texas Archeological Society, and Bulletin No. 4, Texas Memorial Museum, Austin. Reprinted in 2009, Gustav's Library, Davenport, Iowa.

Wilson, A. M. and A. T. Jackson

1930 Field Notes: Work Done at Indian Sites, Wood County, Texas. MS on file, Texas Archeological Research Laboratory, The University of Texas at Austin. 